\title{
Evaluation of efficacy and safety profile of tamsulosin in benign prostatic hyperplasia
}

\author{
Praveen R. ${ }^{1 *}$, Kumar T. N. ${ }^{2}$ \\ ${ }^{1}$ Department of Pharmacology, Venkateshwara Institute of Medical Sciences, Gajraula, Uttar Pradesh, India \\ ${ }^{2}$ Department of Pharmacology, Sree Narayana Institute of Medical Sciences, Ernakulam, Kerala, India
}

Received: 29 October 2019

Revised: 13 December 2019

Accepted: 16 December 2019

\section{*Correspondence:}

Dr. Praveen R.,

Email: drpraveen28@gmail.com

Copyright: (C) the author(s), publisher and licensee Medip Academy. This is an open-access article distributed under the terms of the Creative Commons Attribution Non-Commercial License, which permits unrestricted non-commercial use, distribution, and reproduction in any medium, provided the original work is properly cited.

\begin{abstract}
Background: To evaluate the efficacy and safety profile of alpha-1A receptor subtype specific antagonist-tamsulosin in benign prostatic hyperplasia.

Methods: An open label, non-randomised, prospective, single centred study who were visiting urology department with confirmed diagnosis of benign prostatic hyperplasia (BPH) were included in the study. Thirty patients with BPH were prescribed tamsulosin and were followed up to three months. The initial or baseline data collected were identification of the patients such as international prostate symptom score (IPSS), prostate specific antigen, urine analysis, and ultrasonography of prostate including post void residual urine. The patients were followed up to 3 months to measure clinical and laboratory outcomes (IPSS score, post void residual urine, uroflow rates etc.).

Results: In our study, patients receiving tamsulosin $0.4 \mathrm{mg}$ once daily showed a significant improvement in post-void residual urine (PVRU), uroflow rates and IPSS score. The improvements in the above parameters were found to be statistically insignificant at first and third month of follow-up.

Conclusions: In our study, tamsulosin an alpha-1A receptor subtype specific antagonist showed significant improvement in BPH symptoms and the drug was well tolerated.
\end{abstract}

Keywords: Benign prostatic hyperplasia, Tamsulosin, Post void residual urine

\section{INTRODUCTION}

Benign prostatic hyperplasia (BPH) is one of the most common conditions affecting the elderly males. ${ }^{1}$ The enlargement of the prostate can produce voiding symptoms, which can lead to pathological changes in the urinary bladder and the kidney. ${ }^{2}$

Management of BPH has also changed significantly with a considerable advance in the understanding of the demographics and natural history of the disease. ${ }^{3}$

The pharmacotherapy of BPH comprises of alpha- 1 receptor antagonists, 5-alpha reductase inhibitors, phytotherapy, gonadotropin releasing hormone analogues and androgen receptor blockers.

Among the alpha-1 receptor blockers, tamsulosin is being the gold standard which is a specific alpha- 1 receptor blocker being used to treat BPH. The present study is undertaken since the studies from Indian perspective are limited.

\section{METHODS}

A prospective study was conducted from October 2005 to September 2006 on patients attending urology department with $\mathrm{BPH}$. 
The study was conducted on both outpatients and inpatients of R.L. Jalappa Hospital and Research Centre, attached to Sri Devaraj Urs Medical College, Tamaka, which is situated near Kolar.

A proforma containing detailed information on each patient was prepared according to the protocol designed for the study. Informed consent was taken from all the patients included in the study. Ethical clearance was obtained from the institutional ethics committee. The following inclusion criteria were considered to get the right patient into the study.

\section{Inclusion criteria}

Patients greater than 45 years of age with clinical diagnosis of symptomatic BPH. Patients with IPSS score more than four at the base line, PSA value of less than 10 $\mathrm{ng} / \mathrm{ml}$. Patients with maximum urinary flow rate of $\leq 12$ $\mathrm{ml} / \mathrm{s}$ but $\geq 4 \mathrm{ml} / \mathrm{s}$ for a voided volume of $\geq 120 \mathrm{ml}$ were included.

\section{Exclusion criteria}

Patients suspected to be having carcinoma of prostate. PSA value of more than $10 \mathrm{ng} / \mathrm{ml}$. Neurogenic bladder cases. Patients with upper motor lesions, urethral strictures and urinary bladder stones. Patients who have undergone previous prostate surgery and patients with known hypersensitivity to alpha-1 blockers were excluded.

Relevant data were taken from the patients with benign prostatic hyperplasia. The data included hospital number, name, age of the patient, dates of visiting the outpatient department (OPD) and the dates of admission and history of presenting illness. The proforma also enlisted general physical examination, vital signs like blood pressure, heart rate, systemic examination like cardiovascular system and abdomen examination including digital per rectal examination.

Laboratory investigations included random blood sugar, prostate specific antigen and urine analysis. The ultrasonography investigations were done to measure the size of the prostate and post void residual urine. The uroflow meter analysis was done as an OPD procedure.

The assessment of the symptoms was done by using International prostatic symptom score (IPSS) which was given to patient on the very first time of visiting the OPD, first month and then the third month, to assess the symptomatic improvement. The uroflow meter analysis, ultrasonography of the size of the prostate and the post void residual urine was done at the base line, first month, and on the third month of the follow up to assess the clinical improvement.

Tamsulosin $0.4 \mathrm{mg}$ once daily was prescribed to patients who were eligible as per the inclusion and exclusion criteria. The patients were advised to come for the follow up on the first month and the third month of the treatment. The data obtained were analysed by using student two tailed test, repeated outcomes were measured using ANOVA to find the significance of the study parameters between onset, first month and third month respectively.

\section{RESULTS}

There was no relevant statistical difference between the treatment groups in terms of demographic changes as the mean being 62.57 years in the tamsulosin group.

The baseline IPSS were measured and compared with first and third month. The baseline score was 26.73 in the study group and reduced significantly at (15.73) first month and reduced further at (9.13) third month.

Table 1: IPSS score in tamsulosin arm.

\begin{tabular}{|lll|}
\hline IPSS score at various intervals & Mean & \pm SD \\
\hline Baseline & $26.73^{*}$ & \pm 4.45 \\
\hline First month & 15.73 & \pm 3.25 \\
\hline Third month & $9.13^{*}$ & \pm 2.34 \\
\hline \% change & 64.7 & \\
\hline$* \mathrm{p}<0.001$ & & \\
\hline
\end{tabular}

\section{Comparison of prostate specific antigen $(\mathrm{ng} / \mathrm{ml})$ score in tamsulosin arm}

The carcinoma of prostate will also mimic the symptoms of BPH, to rule out the carcinoma the prostate specific antigen (PSA) was measured at each interval to exclude any false positive cases.

There is no change in the PSA values from baseline till the end of study. The PSA remains unaltered in each and every time point.

Table 2: Comparison of PSA score in tamsulosin arm.

\begin{tabular}{|lll|}
\hline PSA $(\mathrm{ng} / \mathrm{ml})$ & Mean & $\pm \mathrm{SD}$ \\
\hline Baseline & 2.74 & \pm 1.32 \\
\hline First month & 2.74 & \pm 1.32 \\
\hline Third month & 2.74 & \pm 1.32 \\
\hline \% change & - & \\
\hline
\end{tabular}

Table 3: PVRU at baseline at first and third months.

\begin{tabular}{|l|l|}
\hline Intervals & PVRU $(\mathrm{ml})$ \\
\hline Baseline & 78.16 \\
\hline First month & 39.16 \\
\hline Third month & 20.83 \\
\hline
\end{tabular}

\section{Comparison of post-void residual urine $(\mathrm{ml})$ score in the tamsulosin group}

The effects of tamsulosin on the post-void residual urine (PVRU) is shown in the below figure, there were 
significant reductions from baseline to the end of third month in both the treatment groups $(\mathrm{p}<0.001)$.

\section{Comparison of uroflow $(\mathrm{ml} / \mathrm{s})$ score at baseline to third months}

The changes in $\mathrm{Q}_{\max }$ during the active treatment are shown in the table below there was a significant increase in $\mathrm{Q}_{\max }$ relative to baseline in the treatment group at first and third months $(\mathrm{p}<0.001)$. The maximum increase in the $\mathrm{Q}_{\max }$ was obtained at third month.

Table 4: Comparison of uroflow score at baseline to third months.

\begin{tabular}{|lll|}
\hline Uroflow $(\mathrm{ml} / \mathrm{s})$ & Mean & \pm SD \\
\hline Baseline & $7.37 *$ & \pm 2.44 \\
\hline First month & 14.47 & \pm 4.83 \\
\hline Third month & $25.83^{*}$ & \pm 6.66 \\
\hline \% change & 250.47 & \\
\hline
\end{tabular}

$* \mathrm{p}<0.001$.

\section{DISCUSSION}

Benign prostatic hyperplasia is one of the most common conditions affecting elderly males with a resultant impact on the medical practice as the elderly constitute an increasing population not only in India but also throughout the world. $^{2}$ A decade back, surgery and watchful-waiting were the only accepted management options for BPH. Now there has been a drastic decline in the surgery as medication has become the most frequently used treatment for $\mathrm{BPH}$ that has been a major change in urological clinical practice.

In our study, we have analysed the efficacy of tamsulosin $0.4 \mathrm{mg}$ once daily on IPSS, PSA, PVRU, size of the prostate, uroflow analysis and per rectal examination.

The treatment with tamsulosin resulted in a significant decrease in the mean change from baseline in the total IPSS. The improvement in the total IPSS with tamsulosin was apparent at the first assessment (4 weeks) and was maintained throughout the study. The mean change from baseline in the total IPSS after 12 weeks of treatment was significant $(\mathrm{p}<0.001)$ in concurrence with the study of Nordling. ${ }^{4}$ The mean reduction in total symptom score at the endpoint was $9.43(64.7 \%)$ in the tamsulosin group.

Perhaps a study of longer duration of six months or more may show definite difference in improvement in the effect of one drug over the other. In analysing the PSA values, in our study where the follow-up was up to 12 weeks has shown no statistical change in both the groups. In the study conducted by Park et al, which involved 211 patients treated with tamsulosin, also shows no significant change in the PSA values up to 52 weeks. ${ }^{1}$
In the present study with tamsulosin the post void residual urine showed a significant reduction from the baseline till the third month $(\mathrm{p}<0.001)$, in concurrence with the study of Rosette et al involving 101 patients on alfuzosin and 86 patients on tamsulosin. ${ }^{5}$

In the uroflowmetry analysis, there was a significant increase in $\mathrm{Q}_{\max }$ relative to baseline in treatment group at each time $(\mathrm{p}<0.001)$ i.e., baseline to first month and from first month to third month. The maximum increase in the $\mathrm{Q}_{\max }$ was obtained at third month in both the group. As per the meta-analysis of two European randomized, double blind, multicentric studies with tamsulosin for 12 weeks, a significant improvement in $\mathrm{Q}_{\max }$ from baseline has been reporte, and similar findings have been found in the present study also. 6,7

As for the size of the prostate is concerned, in our study there was no significant change in the size of the prostate in the treatment arm which was also similar to a study done by Rossette et al. ${ }^{5}$ In our study, tamsulosin was well tolerated, and the treatment emergent adverse events were not serious enough to warrant withdrawal from the study. A study conducted by Roehrborn et al also states similar findings and the same quoted in other review articles too. ${ }^{8}$

In the present study side effects were low and compliance was equally good with both the drugs. Retrograde ejaculation was not complained by any of our patients in the study, however most of the patients were elderly coming from a low socio-economic status with a rural background who also followed good old Indian traditions like staying in a joint family how much ever the couples believed in the indulgence of the sexual activity is uncertain.

\section{CONCLUSION}

The results of the present study show that tamsulosin 0.4 $\mathrm{mg}$ once daily in the treatment of BPH produce improvement in urinary flow rates, symptoms and post void residual urine and the study drug was well tolerated, thus maintaining the improvement in the lower urinary tract symptoms.

\section{Funding: No funding sources \\ Conflict of interest: None declared}

Ethical approval: The study was approved by the Institutional Ethics Committee

\section{REFERENCES}

1. Park CH, Chang HS, Oh BR, Hung KM, Sul CK, Chung SK, et al. Efficacy of low dose tamsulosin on lower urinary tract symptoms of benign prostatic hyperplasia. J Clin Drug Invest. 2004;24(1):41-7.

2. Marberger M, Horkaway R, Rosette JD. Optimising the medical management of benign prostatic hyperplasia. J Eur Urol. 2004;45:411-9. 
3. Tanaka Y, Naoya M, Itoh N, Sato Y, Takahashi A, Ogura $\mathrm{H}$, et al. Urodynamic effects of terazosin treatment for japanese patients with symptomatic benign prostatic hyperplasia. J Urol. 2002;167:2492-5.

4. Nordling J. Efficacy and safety of two doses (10 and $15 \mathrm{mg})$ of alfuzosin or tamsulosin $(0.4 \mathrm{mg})$ once daily for treating symptomatic benign prostatic hyperplasia. BJU Inter. 2005;95(7):1006-12.

5. Rosette JJ, Mathew PH, Connor SE, Cockett A, Druker BJ. Response of prostate volume and prostate specific antigen to tamsulosin and alfuzosin in men with benign prostatic hyperplasia. $\mathrm{J}$ Urol. 1993;9:123-31.
6. Hannah C, Goa KL. Dutasteride. J Drugs Aging. 2003;20:905-16.

7. Cockrum PC, Finder SF, Ries AJ, Potyk RP. A pharmacoeconomic analysis of patients with symptoms of benign prostatic hyperplasia. $\mathbf{J}$ Pharmacoeconomics. 1997;11:550-65.

8. Praveen R. Tamsulosin turn around. Int $\mathbf{J}$ Cur Bio Med Sci. 2011;1(2):39-40.

Cite this article as: Praveen R, Kumar TN. Evaluation of efficacy and safety profile of tamsulosin in benign prostatic hyperplasia. Int $\mathbf{J}$

Basic Clin Pharmacol 2020;9:332-5. 